\title{
REFLEKSI NILAI ADAB DAN HUBUNGAN HORIZONTAL DALAM NASKAH BABAD AWAK SALIRA
}

\author{
REFLECTION MORAL VALUES AND HORIZONTAL \\ RELATIONSHIPS IN MANUSCRIPT BABAD \\ AWAK SALIRA
}

\author{
Isep Bayu Arisandi ${ }^{1}$, Titin Nurhayati Ma'mun ${ }^{2}$ dan \\ Undang Ahmad Darsa ${ }^{3}$ \\ ${ }^{.1 .2 .3}$ Fakultas Ilmu Budaya, Universitas Padjadjaran, Bandung, Indonesia \\ isepbayu@gmail.com
}

DOI: 10.31291/jlka.v19.i2.995

Diterima: 15 September 2021; Direvisi: 15 Desember 2021;

Diterbitkan: 31 Desember 2021

\begin{abstract}
The value of moral affects the horizontal relationship that exists between humans. This is recorded in the ancient texts of the Islamic period as evidence of the influence of Islamic teachings that entered the archipelago. The disclosure of this moral value is an effort to "share" the heritage of the ancestors, as well as a reflection on the current conditions that are quite relevant. The Babad Awak Salira (BAS) manuscript, one of the written heritages in Tatar Sunda, contains very strong moral values. The problems revealed in this paper, namely; (1) the values of moral contained in the text of the BAS manuscript; and (2) the effect of moral reflection in the horizontal relationship. This paper aims to reveal the values of moral and their influence on horizontal relationships. This research is a literature research, descriptive analysis. Due to the fact that the object is an ancient text, a philological approach is used to study the BAS text. Seeing this, the relevance of the existence of values in the ancient texts (which are time apart) is so eternal in didactic wraps. The existence of content values can also be seen as a piece of advice and a "treasure" of inheritance in a written tradition in Tatar Sunda, in general in the archipelago. Disclosure of the value of the content of ancient manuscripts, can be seen as an effort
\end{abstract}

Jurnal Lektur Keagamaan | p-ISSN: 2620-522X, e-ISSN: 1693-7139

This is an open access article under CC-BY-NC-SA license

(http://creativecommons.org/licenses/by-nc-sa/4.0/) 
to understand and "bridge" the times, considering that the medium of script is no longer conventional at this time.

Keywords: Manuscript, Text BAS, Moral values, Moral reflection.

\begin{abstract}
ABSTRAK
Nilai adab berpengaruh terhadap hubungan horizontal yang terjalin antarmanusia. Hal ini tercatat dalam naskah kuna periode Islam sebagai bukti pengaruh ajaran Islam yang masuk ke Nusantara. Pengungkapan nilai adab ini sebagai upaya "membagikan" warisan nenek moyang, juga sebagai refleksi atas kondisi zaman saat ini yang cukup relevan. Naskah Babad Awak Salira (BAS), salah satu warisan tulis yang ada di Tatar Sunda, mengandung nilai-nilai adab yang kuat. Masalah yang diungkap dalam tulisan ini, yaitu; (1) nilai adab yang ada di dalam teks naskah $B A S$; dan (2) pengaruh refleksi adab dalam hubungan horizontal. Tulisan ini bertujuan untuk mengungkap nilai-nilai adab dan pengaruhnya terhadap hubungan horizontal. Kajian berjenis studi pustaka, bersifat deskriptif analisis. Sehubungan bahwa objek adalah naskah kuna, digunakan pendekatan filologis untuk mengkaji naskah $B A S$. Melihat hal itu, relevansi keberadaan nilai dalam naskah kuna (yang berjarak zaman) begitu kekal dalam balutan didaktis. Keberadaan nilai kandungan juga dapat dipandang sebagai sebuah petuah dan "harta" warisan dalam sebuah tradisi tulis di Tatar Sunda, secara umum di Nusantara. Pengungkapan nilai kandungan naskah kuna dapat dilihat sebagai upaya memahamkan dan "menjembatani" zaman, mengingat medium aksara sudah tidak konvensional lagi saat ini.
\end{abstract}

Kata kunci: Naskah kuna, Teks $B A S$, Nilai Adab, Refleksi Adab.

\title{
PENDAHULUAN
}

Nilai kandungan yang terdapat dalam naskah kuna sangat beragam dan bernilai luhur. Hal ini berbanding terbalik dengan pengungkapan nilai-nilai yang terkandung dalam naskah kuna, tidak semua kandungan sudah terungkapkan. Keberadaan naskah kuna masih banyak di Nusantara, terbukti dengan penyelamatan yang dilakukan oleh lembaga atau badan swasta di setiap daerah, masih banyak milik perorangan atau keluarga, umumnya diperoleh sebagai harta benda pusaka ${ }^{1}$. Melihat usia naskah yang sudah berumur, daya tahan material naskah yang mudah rapuh 147.

${ }^{1}$ Undang Ahmad Darsa, Kodikologi. (Sumedang: FIB Unpad, 2016), 
dan lapuk, serta penanganan terhadap naskah yang kurang diperhatikan di Nusantara, meskipun saat ini sudah beragam cara untuk merawat naskah sudah $\operatorname{ada}^{2}$. Salah satu yang menjadi faktor adalah iklim yang panas dan lembab di Indonesia dapat berpengaruh terhadap daya tahan naskah ${ }^{3}$. Oleh karena itu, pengungkapan nilai kandungan naskah kuna patut menjadi perhatian, pengungkapan nilai kepada masyarakat luas sangat penting dilakukan untuk memahami nilai kandungan naskah kuna yang didaktis sangat diperlukan saat ini.

Beragam kandungan yang ada dalam naskah kuna merupakan jejak warisan dari moyang bangsa ini. Nilai kandungan yang ada di dalam naskah kuna sebagai warisan, salah satunya berkaitan dengan etika atau adab. Keberadan nilai kandungan ini tidak dapat dipandang sebelah mata, secara khusus setelah ajaran Islam masuk dan menyebar di Nusantara. Kandungan naskah kuna tidak hanya berupa cerita, hiburan, sejarah, namun terdapat nilai didaktis yang sangat kontekstual yang harus tetap dijaga dan tersampaikan.

Khazanah naskah Nusantara yang tersedia saat ini, tidak lepas dari peran penulis atau penyalin naskah yang berupaya "menusantarakan" dari sumber asing, sehingga melahirkan beragam versi -bahkan varian. Hal tersebut menjadi corak dan kekhasan naskah di Nusantara ${ }^{4}$. Hal ini terjadi seiring masuknya ajaran Islam di Nusantara. Sejak itu, kegiatan menulis (dan menyalin) nilai-nilai ajaran Islam di dalam naskah Nusantara berpengaruh besar terhadap produksi naskah di Nusantara.

Salah satu yang menarik dari penulisan naskah-naskah di Nusantara adalah nilai kandungan yang berkaitan dengan nilainilai adab. Nilai adab di dalam naskah kuna periode Islam di Nusantara sangat beragam, mulai dari hal paling umum sampai spesifik. Hal ini, berkaitan dengan tingginya nilai adab yang dipandang dalam ajaran Islam. Oleh karena itu, ketersebaran

\footnotetext{
${ }^{2}$ Tedi Permadi, Kodikologi Sebuah Pengantar Kajian Naskah. (Bandung: FPBS UPI, 2011), 83.

${ }^{3}$ Sri Wulan Rujiati Mulyadi, Kodikologi Melayu Di Indonesia. (Fakultas Sastra, Universitas Indonesia, 1994), 79.

${ }^{4}$ Oman Fathurahman, "Karakteristik Naskah Islam Indonesia: Contoh Dari Zawiyah Tanoh Abee, Aceh Besar”, Manuskripta, 1, no. 1 (2011), 127.
} 
nilai adab dalam naskah kuna menunjukkan pentingnya adab dalam relasi sosial.

Naskah Babad Awak Salira (selanjutnya disebut BAS) merupakan naskah yang ditemukan di wilayah Tatar Sunda. Keberadaan naskah kuna di Tatar Sunda menjadi refleksi atas setiap bentuk adab dan kebiasaan yang ada di Sunda. Melalui tulisan ini, diketahui naskah $B A S$ mengandung nilai adab secara umum. Adab secara umum yang dimaksud adalah setiap perilaku manusia dalam menjalin hubungan dengan sesama di lingkungan masyarakat.

Pemanfaatan kajian fiologis untuk mengungkapkan nilai kandungan dalam naskah kuna patut dijadikan pemahaman dasar. Pemahaman filologis dapat diartikan sebagai wawasan terhadap sebuah hasil atau proses budaya yang mempertanyakan lima unsurnya, artefaktualitas, ketercapaian, ketersusunan, kontekstualitas, dan historitas - yang mempertanyakan keterkaitan unsur itu satu sama lain ${ }^{5}$. Tulisan ini sampai pada kontekstualitas, tidak menyentuh unsur historitas yang ada di dalam naskah $B A S$.

Meskipun tidak sampai pada penelusuran sisi historitas, adanya nilai-nilai yang terkandung di dalam naskah akan memberikan pemahaman dan kontekstualitas atau relevansi dengan kondisi saat ini. Pemahaman terhadap nilai kandungan yang luhur dapat dimulai dengan penyampaian dan pengejawantahan nilai tersebut. Luhurnya nilai adab yang harus tersampaikan, berkaitan dengan upaya menjalin hubungan secara horizontal dalam kehidupan sehari-hari. Oleh karena itu, upaya yang dilakukan dapat dilihat selain penyebaran dan penyampaian nilai, juga pemahaman terhadap nilai yang ada.

Pengetahuan dan pemahaman mengenai nilai adab dapat memberikan dampak dalam menghadapi perkembangan zaman yang begitu cepat. Pengetahuan dan pemahaman mengenai nilai adab akan membuka dan mengembalikan hakikat manusia kepada lingkungan sosial dan hubungan yang terjalin dalam nilai sosial. Hal itu didorong bahwa adab merupakan sebuah refleksi atas diri sendiri. Melalui pengungkapan nilai yang terkandung

${ }^{5}$ Bernard Arps, "Kepekaan Filologis Untuk Pengkajian Budaya," Manuskripta 10, no. 2 (2020), 177-191. 
dalam teks $B A S$, dapat mengingatkan masyarakat atas nasihatnasihat, pepatah, dan sebagai bentuk peringatan. Setiap bentuk peringatan yang tertulis dalam teks $B A S$ tidak selalu berbentuk larangan, tetapi berbentuk solusi untuk manusia dalam menjalin hubungan horizontal. Istilah hubungan horizontal, secara praktis dapat dikatakan sebagai hubungan antarmanusia yang muncul dalam membangun interaksi dan relasi sosial.

Adab erat kaitannya dengan moral yang berasal dari bahasa Latin mos (jamak mores) berarti mengandung adat kebiasaan dan norma yang menjadi pegangan hidup, pengaturan tingkah lakunya. Moral bukan sekadar sesuatu yang deskriptif tentang baik, melainkan sesuatu yang mengarahkan kelakuan dan pikiran seseorang untuk berbuat baik. Moralitas menuntut seseorang melaksanakan yang baik dan menolak yang bathil ${ }^{6}$. Melalui definisi tersebut, keterkaitan moral dalam berperilaku di lingkungan patut menjadi perhatian. Hal itu sebenarnya sudah tertulis dan menjadi acuan atas amanat-amanat yang ada dalam nilai kandungan naskah kuna. Pemahaman mengenai nilai adab akan menjaga nilainilai sosial serta dapat menjadi pegangan hidup.

Fokus permasalahan mengenai kompleksitas nilai adab yang terkandung dalam teks diungkapkan melalui beberapa permasalahan yang ada terkait nilai kandungan teks naskah $B A S$. Permasalahan yang diurai dalam tulisan ini meliputi; (1) bagaimana nilai adab yang ada di dalam teks naskah $B A S$; dan (2) bagaimana pengaruh refleksi adab dengan hubungan horizontal.

Pemilihan naskah BAS sebagai objek didasari atas keberadaan naskah kuna yang saat ini sudah sulit ditemukan. Selain itu, nilai kandungan yang terdapat di dalam naskah penting untuk diungkapkan dan dipahami oleh umum. Pengungkapan nilai kandungan dalam naskah, berkaitan dengan upaya memudahkan pemahaman karena aksara yang digunakan di dalam naskah sudah tidak familiar lagi pada masyarakat masa kini. Oleh karena itu, pengungkapan nilai yang terkandung di dalam naskah kuna menjadi perhatian untuk diungkapkan.

${ }^{6}$ Nurul Zuriyah, Pendidikan Moral Dan Budi Pekerti Dalam Perspektif Perubahan. (Jakarta: Bumi Aksara, 2007), 12-17. 
Kajian terhadap nilai-nilai yang terkandung dalam naskah di Jawa yang berkaitan dengan nilai etika lebih mudah ditemui daripada naskah di Tatar Sunda. Ditemukan beberapa kajian yang mengungkapkan kandungan nilai adab dalam naskah di Jawa. Pertama, kajian terhadap ajaran Nistha-Madya-Utama yang ada dalam teks Nitisruti, Serat Sewaka, Nitipraja, Panitisastra Kawi-Miring, dan Wicara Keras. Hasil kajian menunjukkan bahwa ajaran moral dan etika dalam masyarakat di Nusantara sudah memiliki ciri dan identitas yang berbeda dengan kepribadian masyarakat lainnya. Ajaran bukan yang mandiri, tetapi digunakan sebagai unsur dari sejumlah unsur lainnya ${ }^{7}$. Kedua, kajian terhadap Serat Sanasumu karya Kyai Yasadipura II. Ajaran catur budi yang terdapat di dalam naskah tersebut merupakan ajaran untuk pembentukan watak kepribadian yang didasarkan pada nilai-nilai positif dari berbagai kelas, yaitu priyayi, santri, petani, dan saudagar ${ }^{8}$. Ketiga, kajian terhadap naskah Serat Wulang Sunu yang menunjukkan unsur didaktis dalam kandungannya ${ }^{9}$. Ajaran didaktis yang tertuang di dalamnya meliputi: berbakti kepada orangtua, menjauhi perbuatan tercela, dan silaturahmi antarsaudara di dalam keluarga. Keempat, kajian terhadap naskah Serat Darmasaloka ${ }^{10}$, terdapat nilai moral untuk perempuan, ajaran tasawuf, ajaran rukun dan hormat, serta ajaran Islam. Adanya bentuk ajaran tersebut disampaikan untuk mencapai suatu kesempurnaan hidup yang bersumber dari ajaran Islam. Kelima, kajian terhadap naskah Serat Wulang Pandhita Terkawadi ${ }^{11}$. Nilai luhur yang

${ }^{7}$ Christiana Dwi Wardhana, "Ajaran Nistha-Madya-Utama Dalam Beberapa Teks Jawa," Jumantara: Jurnal Manuskrip Nusantara 1, no. 2 (2019): $1-10$.

${ }^{8}$ Christiana Dwi Wardhana, "Ajaran Catur Budi Dalam Serat Sasanasunu Karya Kyai Yasadipura II," Jumantara: Jurnal Manuskrip Nusantara 5, no. 1 (2014): 150-159.

${ }^{9}$ Kamidjan Kamidjan, "Naskah Serat Wulang Sunu Sebuah Sastra Didaktis: Kajian Filologi,” Jurnal Pena Indonesia 1, no. 2 (2015): 216-239.

${ }^{10}$ Syaiful Rohman and Dewaki Kramadibrata, "Piwulang Dalam Serat Darmasaloka," Jumantara: Jurnal Manuskrip Nusantara 9, no. 2 (2018): 223-238.

${ }^{11}$ Titi Mumfangati, "Kajian Nilai Budaya Dalam Serat Wulang Pandhita Tekawardi," Patrawidya 18, no. 2 (2017): 203-219. 
terkandung dalam naskah ini dapat dijadikan sebagai pedoman tingkah laku dan sumber pengembangan mental. Nilai-nilai yang terkandung di dalam naskah meliputi nilai religius, moral, ketatanegaraan, kesetiaan, keteladanan, etika, kepemimpinan, dan didaktis. Kuatnya unsur nilai moral dalam naskah dapat menjadi pedoman dalam bertingkah laku saat ini. Keenam, kajian terhadap naskah Serat Wulangreh karya Pakubuwono IV dalam pupuh macapat Durma ${ }^{12}$. Nilai kandungan dalam naskah ini memiliki relevansi yang besar dengan kondisi masyarakat saat ini. Adanya nasihat untuk mengendalikan diri yang berpijak pada nilai religi dapat meningkatkan membangun hubungan baik melalui perilaku budi pekerti.

Nilai dan ajaran budi pekerti tidak hanya melalui kandungan teks saja, melainkan juga dapat dilihat dari iluminasi. Kajian ketujuh, mengungkap ajaran budi pekerti yang terdapat dalam iluminasi naskah Babad Kartasura-Sukawati. Ajaran budi pekerti yang berhasil diungkapkan meliputi; (1) ajaran kepemimpinan, dapat dilihat dari iluminasi burung garuda yang terwakili dari bentuk sayap kiri dan kanan yang bersatu, sedangkan ekornya menggambarkan keagungan serta kewibawaan; (2) berpekerti luhur, dapat dilihat melalui iluminasi songsong (payung emas) yang melambangkan kebesaran Raja yang menjadi penguasa saat itu ${ }^{13}$. Kedelapan, kajian terhadap naskah Tafsir AlHuda yang mengandungan budi pekerti dan akhlak. Nilai etika budaya Jawa yang terdapat dalam naskah ini mencakup hubungan manusia dengan Sang Pencipta, interaksi antarsesama manusia, dan mencintai lingkungan alam semesta ${ }^{14}$.

Keberadaan naskah-naskah di Jawa yang mengandung nilai moral, adab, atau perilaku yang mudah ditemui menjadi dasar tulisan ini, berpijak pada naskah yang berada di Tatar Sunda.

\footnotetext{
${ }^{12}$ Bremara Sekar Wangsa, Edy Tri Sulistyo, and Suyanto Suyanto, "Makna Budi Pekerti Remaja Pada Serat Wulangreh Karya Pakubuwono IV: Pupuh Macapat Durma," Mudra Jurnal Seni Budaya 34, no. 3 (2019): 325329.

${ }^{13}$ Venny Indria Ekowati et al., "Ajaran Budi Pekerti Dalam Iluminasi Naskah Babad Kartasura-Sukawati," Manuskripta 8, no. 1 (2018): 129-157.

${ }^{14}$ Novita Siswayanti, "Javanese Ethical Values in Tafsir Al-Huda," Analisa Journal of Social Science and Religion 20, no. 2 (2013): 207-220.
} 
Keberadaan naskah kuna di Tatar Sunda tidak kalah melimpah, salah satunya nilai adab yang terkandung di dalam naskah $B A S$. Melalui tulisan ini, akan membuka pandangan secara khusus bahwa di Tatar Sunda juga harus mendapatkan perhatian, terlebih naskah kuna yang memiliki nilai kandungan adab.

Hasil kajian terdahulu yang telah diuraikan di atas, membuktikan bahwa setiap daerah di Nusantara memiiki keterkaitan yang selaras antara individu dengan sosial. Perbedaan yang kentara antara kajian ini dengan kajian terdahulu terletak pada; (1) objek naskah; (2) fokus pembahasan; dan (3) relevansi nilai saat ini. Pengungkapan ini diharapkan dapat mempengaruhi masyarakat dalam memahami dan mengamalkan nilai-nilai adab yang sudah tertulis dalam naskah kuna. Selain itu, untuk menjaga nilai-nilai yang terdapat di dalam teks, dengan cara memberikan pemahaman dan memanfaatkan naskah untuk mengatasi masalah-masalah yang terjadi pada masa kini.

Studi pustaka (library research) digunakan dalam tulisan ini yang bertujuan untuk mengumpulkan data-data dan informasi dengan bantuan buku, majalah, cetakan, dan dokumen lain yang relevan $^{15}$. Kajian dalam tulisan ini bersifat deskriptif analisis, berarti menganalisis dengan menggambarkan, melaporkan, menulis objek berdasarkan temuan data.

Kemudian sehubungan dengan objek berupa naskah kuna, maka digunakan kajian filologis, deskripsi dan interpretasi. Deskripsi digunakan untuk menjabarkan (mendeskripsikan) nilainilai kandungan adab yang ada di dalam teks, kemudian interpretasi digunakan untuk menemukan relevansi serta refleksi nilai adab dengan kondisi saat ini. Refleksi yang ada sebagai pengejawantaan dari relevansi kondisi sosial, dapat memberikan sebuah pengajaran atau belajar untuk mengetahui dan melakukan.

\section{HASIL DAN PEMBAHASAN}

Upaya pemahaman nilai kandungan yang tersimpan dalam naskah kuna dapat dilakukan dengan pengungkapan atas nilai kandungan. Pengungkapan nilai kandungan dibahas sesuai

${ }^{15}$ Kartini Kartono, Pengantar Metodologi Research Sosial. (Bandung: Alumni, 1983), 20. 
dengan yang terkandung di dalam teks naskah $B A S$. Pengungkapan nilai kandungan berkaitan dengan pemahaman terhadap nilai-nilai, serta upaya pengalih-bahasaan yang dilakukan melalui kajian filologis. Upaya pengalih-bahasan dilakukan untuk "mendekatkan" teks yang ditulis pada masa lalu dengan saat ini, mengingat aksara yang digunakan tidak familiar lagi di masyarakat.

Keberadaan nilai-nilai dalam teks $B A S$ dibalut dengan penyampaian estetika puisi lama, yaitu wawacan. Nilai kandungan terdapat dalam pupuh pangkur, asmarandana, durma, dan sinom. Setiap pupuh menggambarkan karakter masing-masing: pangkur memiliki karakter sedang mengadakan perjalanan (berpergian), nafsu, dan menggambarkan keadaan siap berperang; asmarandana memiliki karakter bersifat birahi, saling mengasihi, cinta-mencintai, dan semangat birahi yang terbakar; durma memiliki karakter marah, bertengkar, berkelahi, dan suasana perang; serta sinom memiliki karakter gembira dan senang ${ }^{16}$.

Kekhasan bentuk puisi lama yang terikat dengan sistem konvensi, nilai yang ingin disampaikan, dan karakter yang terbangun dalam setiap pupuh harus memiliki korelasi. Oleh karena itu, upaya untuk mengapresiasi bentuk puisi lama ini tidak terbatas pada pengungkapan nilai kandungan saja, tetapi juga mengangkat nilai-nilai didaktis tanpa meniadakan penggunaan sistem konvensi dalam puisi lama.

Melihat gejala tersebut sebagai sebuah kekhasan, maka korelasi yang tepat dengan nilai adab yang terkandung menjadi pijakan karakter setiap pupuh. Berdasar pada semua itu, satu sisi korelasi antara nilai adab, kandungan teks, serta karakter yang terbangun melalui pupuh sudah dilakukan dengan sangat luhur dalam naskah kuna dan tidak "menyeleweng" dari sistem konversi. Kemudian, struktur setiap pupuh yang menjadi perhatian, dengan adanya sistem konvensi yang dapat dipandang besarnya upaya improvisasi yang tetap terikat. Gejala-gejala tersebut tidak akan dibahas dalam tulisan ini, yang menjadi fokus pada tulisan

${ }^{16}$ R. Satijadi Brata, Rusiah Tembang Sunda. (Djakarta: Balai Pustaka, 1952); Ma'mur Danasasmita, Wacana Bahasa Dan Sastra Sunda Lama. (Bandung: STSI Press, 2001). 
ini adalah nilai-nilai adab yang terkandung di dalam teks naskah $B A S$.

\title{
1. Nilai Adab dalam Teks Naskah $B A S$
}

Nilai-nilai adab yang tertulis di dalam teks dimulai dalam pupuh pangkur sebagai "pengantar". Keberadaan pupuh pangkur untuk mewadahi kandungan nilai adab, sesuai dengan karakter yang terbangun dalam pupuh yaitu nafsu dan keadaan siap berperang. Sebagai "pengantar" dapat dimaknai bahwa nafsu di sini adalah sebuah hambatan yang berdampak buruk dalam bentuk perilaku, sedangkan siap berperang, melihat nilai kandungan adalah kesiapan manusia (individu) untuk melawan sifat dan perilaku buruk yang berdampak pada hubungan dengan manusia.

\begin{abstract}
VII/01/187 //Pangkur anu dicarita/ /babagéyan jalma hurip/ /nu awon reujeung nu alus//kudu pada uninga/ ladat watek éta kudu pada maphum/ /sarta adab tatakrama//mangka éling beurang peuting//.

Terjemahan bebas:

VII/01/187 //Pangkur yang diceritakan/ /untuk yang (masih) hidup/ /baik dan buruk/ /harus memahami/ /sifat dan watak/ /serta perilaku//harus ingat siang dan malam//.
\end{abstract}

Kutipan teks di atas, merupakan petuah yang dikhususkan kepada manusia yang masih hidup dan masih melakukan interaksi sosial. Adab-adab yang ada saling berkaitan dan menjalin keterkaitan guna menjadi pijakan dalam melakukan aktivitas sehari-hari. Melalui nilai adab yang tercantum dalam teks, dapat dipahami sebagai petuah yang harus dilakukan oleh manusia. Penggunaan aksara Arab (Pegon) sedikit menghambat penyampaian kepada masyarakat luas sebagai orientasi dalam adab atau perilaku. Melalui penggunaan kajian filologis dalam mengalih aksara dan bahasa akan memudahkan pemahaman nilai-nilai yang terkandung di dalam naskah $B A S$.

Nilai petuah yang ada di dalam kandungan warisan moyang ini, dikhususkan untuk memberikan nilai didaktis sebagai pegangan hidup. Petuah yang ada digunakan untuk menjalani kehidupan, manusia harus mengetahui beragam watak dan adab 
yang ada, baik atau buruk. Hal itu disampaikan sebagai sebuah pedoman dan batasan dalam melangsungkan relasi sosial seharihari. Sebagai sebuah petuah, nilai-nilai adab dan pengetahuan watak merupakan pijakan untuk berperilaku serta menilai orang lain. Bukan tanpa sebab, ketika mengetahui watak orang, dapat menyesuaikan dan memahami sebagai respons dari diri sendiri terhadap lingkungan.

Melalui nilai-nilai adab ini, terungkap sifat dan watak tercela yang sering ditunjukkan oleh manusia. Nilai adab yang berkorelasi dengan sifat dan watak berpengaruh kepada manusia. Layaknya sebuah petuah, nilai-nilai buruk yang harus dijauhi oleh manusia dijelaskan dengan saksama dalam kandungan teks.

\title{
Watak Tercela
}

Menilik nilai adab dalam kandungan teks, pertama berkaitan dengan watak tercela yang ada dan harus dijauhi oleh setiap manusia. Hal ini bertujuan untuk memberikan gambaran sekaligus membatasi manusia dari hal-hal buruk yang akan terjadi. Watak tercela yang ada kemudian dijadikan sebuah istilah sebagai corak estetika sebuah puisi. Dapat disimak melalui cuplikan teks dalam pupuh pangkur berikut ini.

\begin{abstract}
VII/21/207 //Aya satengah carita/ /babasaan watek genep perkawis/ /mimitina basa lunyu/ lémér anu kaduwa/ /basa ganjah nyaéta anu katilu//kaopatna angrong sanak/ /kalima sumur gumuling//. VII/22/208 //Ari basa kagenepna/ laya éta basa ngabuntut arit/ /percékana mun dicatur//mungguh hiji2na/....

Terjemahan bebas:

VII/21/207 //Setengah cerita (tulisan)/ /watak (terbagi) enam jenis/ /kesatu disebut lunyu/ /kedua lémér/ /ketiga ganjah/ /keempat angrong sanak/ /kelima sumur gumuling//. VII/22/208 //keenam/ /disebut ngabuntut arit/ /pahami yang disampaikan//satu persatu/....
\end{abstract}

Melalui dua cuplikan teks di atas, dapat disampaikan bahwa ada enam watak tercela yang layak dijauhi oleh manusia: lunyu, lémér, ganjah, angrong sanak, sumur gumuling, dan ngabuntut arit. Keenamnya merupakan watak yang sering mun- 
cul dari manusia. Dijelaskan bahwa istilah lunyu adalah orang yang tidak dapat menyimpan uang (materi), tidak dapat mengolah dan menggunakan finansial dengan baik.

Istilah lémér dapat dimaknai sebagai watak yang mudah tergoda oleh materi dunia. Watak seperti ini harus dijauhi oleh setiap manusia dalam memandang materi duniawi, tidak boleh diterapkan sebagai orientasi. Keinginan terhadap materi duniawi tidak akan pernah ada habisnya sepanjang usia, sepanjang menjalani hidup. Istilah ganjah, tidak jauh berbeda dengan keinginan yang besar, tetapi tidak tercapai. Secara halus, dapat dimaknai sebagai mengawang-ngawang.

Istilah angrong sanak dijelaskan yaitu watak yang sering menggoda istri saudara dan orang lain. Mudah tergoda kepada wanita secara sembunyi mengganggu rumah tangga orang lain. Hal itu berakibat pada perilaku yang jelek terbangun kepada keluarga dan lingkungan. Istilah sumur gumuling dapat dimaknai sebagai perilaku yang sering diperlihatkan dengan semena-mena dalam memerintah. Watak seperti itu berdampak pada perilaku yang tidak dapat dimaafkan dan tidak memiliki hati nurani. Istilah ngabuntut arit dimaknai sebagai watak yang sering menusuk dari belakang. Hal itu ditemui dalam perilaku yang baik di depan, sedangkan di belakang menjelekkan. Setiap ucapan yang keluar dari mulutnya tidak ada yang baik dan tidak patut untuk didengarkan.

\section{Perilaku Buruk}

Adanya watak tercela dalam diri manusia menghadirkan perilaku buruk yang kemudian muncul dalam kegiatan seharihari. Perilaku buruk jelas harus dihindari oleh setiap manusia. Perilaku buruk yang terkandung sebagai peringatan yang harus dijauhi oleh manusia dapat dipahami melalui cuplikan teks dalam pupuh asmaran berikut ini.

XII/13/304 //Aya cacad gedé deui/ /nujadi rereged raba/ Ingalangkungan tina awon//réyana opat parkara//sahiji nginum madat//kaduwa bobotoh ngadu//katilu lampah durjana//. XII/14/305 //Anu kaopat perkawis/ /nyaéta pikir sudagar/.... 
Terjemahan bebas:

XII/13/304 //Ada yang lebih buruk/ /membuat sulit bergerak/ /melebihi keburukan/ /ada empat bentuk (perilaku)//kesatu ngimum madat/ /kedua bobotoh ngadu/ /ketiga lampah durjanal/. XII/14/305 //Keempat//pikir sudagar/....

Melihat catatan di atas, perilaku buruk akan berakibat pada langkah yang sempit dalam sosial. Hal itu didasari atas perilaku yang muncul, yaitu nginum madat, bobotoh ngadu, lampah durjana, dan pikir sudagar. Perilaku buruk ini berdampak pada hubungan dengan lingkungan, sejalan dengan sulitnya melangkah, karena setiap melangkah memiliki cela terhadap orang lain. Patutnya, perilaku seperti ini tidak dilakukan oleh manusia. Selayaknya peringatan, anjuran untuk menjauhi perilaku buruk begitu lekat dan mejadi peringatan kepada semua manusia. Semua itu bertujuan untuk membuka kelonggaran dan hubungan baik antarmanusia.

Keempat perilaku yang dinilai sangat buruk, bahkan mengotori tubuh serta lingkungan, tercantum dalam istilah ngimun madat, dijelaskan akan berdampak pada kebiasaan diam dan terus-terusan menghisap madat. Ketika berhenti menghisap, akan terlihat matanya merah dan setengah tertutup, pucat, dan bibir hitam. Kemudian, napasnya sesak dan batuk akut, tidak suka makan. Ketika tidak menemukan madat, tidak bertenaga, lemas, dan menggigil, berakibat pada menjual semua barang untuk mendapatkan madat.

Istilah perilaku bobotoh ngadu, dapat diartikan sering berbohong, serta sering mengadu (berjudi) dalam segala hal. Setiap hal akan mudah untuk dibuat judi, kemudian berimbas keberanian menjual wasiat dan warisan dari orangtua, tanpa memperhitungkan harga untuk dijadikan modal berfoya-foya. Istilah lampah durjana diartikan sebagai perilaku yang sangat buruk dan tercela, setiap hari (siang dan malam) hanya memikirkan badan sendiri, memperlihatkan barang orang lain dan diakui oleh diri sendiri (atau dikenal dengan istilah adean ku kuda beureum). Pikiran dalam perilaku ini hanya sebatas memikirkan harta saja, dan harus dilihat oleh orang lain. 
Istilah pikir sudagar dapat diartikan sebagai yang memiliki keinginan untung dan materi saja. Setiap hari hanya memikirkan untung saja, menghindari rugi, padahal materi yang dimiliki sangat banyak. Sikap kepada orang lain yang berdagang selalu baik, karena yang diinginkan adalah keuntungan dalam membeli. Watak ini sangat tertarik kepada duniawi dan materi, setiap saat.

\title{
Adab di Depan Umum
}

Nilai adab tidak lengkap tanpa pandangan dari orang lain terhadap perilaku manusia saat berada di lingkungan. Hal ini tidak luput dari penilaian sebagai peringatan dalam teks naskah $B A S$. Dapat dilihat dalam cuplikan teks pupuh durma berikut ini.

\begin{abstract}
XI/07/280 //Mapan aya bebedon tilu perkara//nanging gedé téh teuhing//sahiji-hijina/ /anu tilu parkaral /ulah sok ngagungkeun diri/... XI/08/281 //Reujeung ulah nyanyampah ka pada jalma/ /nu matak sakit ati/ /ari katiluna/ /ulah pisan poyokan//ka jalma sasama hurip/ /cawadan nyela/ léta salah téh teuhing//.

Terjemahan bebas

$\mathrm{XI} / 07 / 280$ //Terdapat tiga bentuk (adab)/ /sangat buruk/ /satu-persatu/ /dari tiga bentuk/ /mengangungkan diri/ .... $\mathrm{XI} / 08 / 281$ //menghina kepada sesama/ /membuat sakit hati/ /ketiga/ /mencela/ /kepada sesama makhluk/ /perilaku mencela//sangat salah//.
\end{abstract}

Cuplikan teks di atas menunjukkan bahwa adab manusia di depan umum harus diperhatikan, sebagai upaya menjaga nilai adab dalam menjaga hubungan antarmanusia. Untuk menjaga hubungan itu, tiga perilaku yang harus dijaga: jangan menyombongkan diri; jangan menghina; dan jangan mencela. Ketiga itu berkaitan dengan ucapan yang ada dan keluar dari mulut manusia. Hal tersebut menunjukkan bagaimana pengaruh ucapan dalam menjalin hubungan antarmanusia. Oleh karena itu, ketiganya patut dijadikan sebuah gambaran sebagai batasan atas hubungan yang terjalin.

Adab dalam berbicara di depan umum, pertama jangan mengangungkan diri (menyombongkan diri). Perilaku menyombongkan diri akan membuat orang lain tidak baik, memandang 
buruk kepada orang-orang yang menyombongkan diri. Menyombongkan diri di depan umum tidak baik karena sifat sombong akan berdampak buruk kepada diri sendiri atau pun kepada orang lain. Hal ini tidak dapat ditawar dan tidak menjadi sebuah opsi.

Kemudian, jangan menghina kepada sesama manusia (makhluk), karena akan membuat sakit hati orang lain. Selain itu, tidak pernah menghina kepada diri sendiri dan tidak pernah menjelekkan diri sendiri. Adab buruk ini berdampak juga pada perasaan orang lain. Sifat menghina kepada sesama, sudah seperti menyampah dalam ucapan dan terlihat menyepelekan orang lain. Jika menghina, sama saja dengan menghina Sang Pencipta karena ingkar atas ciptaannya.

Ketiga, jangan mencela kepada sesama, karena akan menjadi kebiasaan mencela-mencaci kepada orang lain. Semakin dibiarkan akan membuat buruk hubungan yang terjalin. Meskipun, mencela adalah perilaku yang sangat mudah dilakukan oleh manusia dengan mengomentari "kekurangan" orang lain. Mencela berdampak buruk kepada hubungan antarmanusia. Oleh karena itu, mencela tidak disarankan dan harus dibatasi (dengan bentuk) saling mengingatkan. Terlebih, perilaku mencela dapat dilakukan dengan cepat, maka manusia harus bisa menahan "peperangan" nafsu di dalam dirinya sebelum terucapkan.

Peran setiap manusia dalam hubungan relasi harus dapat memberikan peringatan dan mengingatkan kepada orang terdekat untuk menjauhi hal-hal seperti itu. Harus berbudi baik, saling mengingatkan antarsesama, dan menjaga diri atas perilaku dan ucapan. Jika tidak mempan diberi tahu, harus diam saja agar tidak terbawa dan terpancing emosi. Mencela sesama, menyombongkan diri, dan menghina tidak ada yang bagus dan tidak layak dilakukan.

\section{Refleksi Adab dalam Hubungan Horizontal}

Hubungan horizontal yang terjalin dan dijalin oleh manusia, bergantung pada apa yang dilakukan oleh manusia tersebut. Melalui adanya refleksi adab, didapati pengaruh yang akan muncul dari lingkungan sekitar. Mengingat itu, jelaslah bahwa yang sudah tertulis sangat berkaitan erat sebagai petuah untuk menunjang hubungan horizontal. Keberadaan nilai adab, baik atau 
buruk sebagai upaya untuk membatasi perilaku yang ada di dalam diri.

Hadirnya perilaku yang menyimpang di masyarakat, tanpa disadari akan berpengaruh buruk. Batasan nilai-nilai adab itu harus segera ditata ulang, segala batasan yang ada dan bias segera dibentuk kembali. Hasil batasan nilai adab berpijak pada watak, karakter, dan sifat manusia sebagai pertimbangan manusia. Terlebih, nafsu baik dan buruk akan ada dalam diri manusia, sisanya dapat dibatasi melalui perilaku yang dapat terlihat dan dirasakan oleh lingkungan sekitar.

\section{Perilaku Buruk di Masyarakat}

Refleksi adab di masyarakat berkaitan dengan perilaku di tengah-tengah masyarakat muncul dalam teks $B A S$. Perilaku di masyarakat yang buruk terdapat dalam kandungan teks pupuh sinom yang memiliki karakter gembira dan senang. Biasanya, berkaitan dengan perubahan yang muncul dengan istilah "anom" atau "nu ngora". Merujuk hal itu, dapat dipandang sepintas sebagai perkembangan masa muda (remaja) yang sering dihadapkan pada taraf mencoba. Hal ini yang kemudian dijadikan sebagai peringatan perilaku yang buruk dan sering muncul di masyarakat berikut ini.

\section{I/12/012 //Aya deui anu kocap//cacad gawé liwat saking/ /réyana dalapan rupa/ Inya[é]ta ngajinah jeung maling/ /maéhan nginum sopi//bégal nyanyam rampok ngadu/.... \\ Terjemahan bebas: \\ I/12/012 //Ada (perilaku) juga//perilaku buruk//sebanyak delapan (jenis)/ /berzinah dan mencuri//membunuh, minum sopil/membegal, nyanyam, merampok, mengadu (judi)/....}

Melalui cuplikan teks di atas, jenis-jenis perilaku yang buruk dan tidak layak dilakukan di lingkungan masyarakat terdapat delapan perilaku. Delapan perilaku yang buruk dilakukan akan berdampak pada pandangan masyarakat dan kerugian terhadap diri sendiri. Misalkan, perilaku berzina adalah salah satu perilaku yang buruk dan saat ini semakin tidak terkontrol (nafsu) khususnya untuk remaja. Kemudian mencuri, adalah 
perilaku yang buruk dan berakibat pada pandangan masyarakat atas pencuri.

Adanya penjabaran perilaku buruk di masyarakat dapat dipandang sebagai sebuah refleksi yang ada serta relevansi atas kondisi saat ini. Bukan tanpa sebab, hal ini sudah diperingatkan (mungkin) akan terjadi dan memberikan dampak buruk kepada diri sendiri. Lantas, perilaku itu akan berpengaruh besar terhadap hubungan antarmanusia, semakin buruk akan berdampak buruk. Hal ini yang membuat nilai kandungan dalam naskah kuna begitu abadi, sebuah kekekalan yang tidak dapat ditelan oleh zaman. Relevansi yang muncul sangat sesuai dengan kondisi saat ini, dapat dijadikan sebuah peringatan dalam berperilaku.

\section{Watak Buruk Manusia}

Watak manusia dalam membangun hubungan dengan sesama manusia, digambarkan dengan metafora hewan. Watak yang digambarkan berkaitan dengan watak buruk yang menjadi nafsu manusia dalam kehidupan sehari-hari. Dapat dilihat dalam cuplikan teks pupuh asmarandana berikut ini.

VI/06/167 //Sato dijiya[an] parlabi//Adigung tegesna gajah//hl.31//gedé jeung mawa tulaley//ari basa Adiguna/ /oray nu mawa peurah//basa Adigang téh tangtu//tegesna nyaéta kidang//. VI/07/168 //Kidang pangawakan ramping/ /napsuna boga akuan//ngandelkeun lumpat nalengser/ /tarik teu aya kandegna/ /gajah ngandelkeunana//takabur ku gedé luhur//sawawarosa tataga//. VI/08/169 //Oray [gé] napsuna sok diri/ Inyaéta andelanana/ /matih peurah lamun macok/ /nu matak banget wewekas/ /ka anak putu poma/ /ulah wani2 niru/ /angkoh kidang gajah oray/l.

Terjemahan bebas:

VI/06/167 //Misalkan dalam (sifat) binatang//Adigung itu gajah/ /hl.13/ /besar dan memiliki belalai//Adiguna/ /ular membawa bisa//Adigang yaitu//kijang//. VI/07/168 //Kijang berbadan ramping//memiliki nafsu/ /mengandalkan lari/ /sangat cepat//gajah mengandalkan//takabur karena besar dan tinggi//memiliki tenaga//. VI/08/169 //Ular memiliki nafsu/ /menjadi andalan/ /memiliki bisa/ /harus waspada/ /kepada anak cucu//jangan meniru//kijang, gajah, dan ular//. 
Cuplikan teks di atas, menjelaskan bagaimana setiap watak buruk di dalam manusia dapat dimetaforakan dengan watak hewan. Melalui tiga jenis hewan yang berbeda, menunjukkan setiap watak: kijang, ular, dan gajah. Ketiga jenis hewan sebagai metafor dalam watak buruk manusia diasonasikan kijang yang ramping, mengandalkan kecepatan dan kecerdikan. Adapun gajah selalu takabur karena memiliki badan yang besar. Ular pun sama, karena memiliki bisa yang dapat menyerang kepada yang tidak berdaya.

Ketiga metafora, kijang dengan kecerdikan untuk sendiri, gajah dengan takabur karena berbadan besar, dan ular yang memiliki bisa. Korelasi yang tepat dengan karakter yang terbangun dalam pupuh asmarandana, sebagai karakter yang berahi dan nafsu. Dalam arti lain, nafsu yang muncul tidak mengenai cinta-mencintai, tetapi kepada keburukan dan watak di dalam diri manusia. Melalui watak seperti ini, berdampak besar pada lingkungan sosial dan pemahaman kepada diri sendiri.

Ketiga watak ini mutlak harus dihindari sebagai peringatan untuk manusia. Melalui penggambaran ini juga, dampak secara implisit dapat dimaknai kekhawatiran yang dialami oleh manusia adalah kemunculan watak ini, serta dipraktikan dalam kehidupan sehari-hari. Setiap manusia harus menyadari kekurangan dan kelebihannya, jangan sampai melihat dari satu sisi dan memanfaatkan watak buruk yang berdampak besar pada diri sendiri dan lingkungan. Nilai yang terkandung ini dapat dilihat sebagai refleksi dari manusia yang ada di dalam lingkungan sehari-hari.

\section{Cara Memandang Watak di Depan Umum}

Refleksi adab di depan umum menjadi pembahasan yang cukup signifikan dalam kandungan teks $B A S$. Hal ini berkaitan dengan adab yang harus dilakukan sebagai antisipasi di tengahtengah orang lain. Dapat dilihat dalam cuplikan teks berikut ini.

VII/06/192 //Ulama reujeung masiyat/ /nu borangan reujeung jalma(na)wani//durjana bobotoh ngadu//kolot jeung anu ngora/ istri sarta lalaki sakabéh tangtu//sok katémbong perwatekna//dina dirina pribadi//. VII/07/193 //Nyaéta di opat rupa/ /sok kaciri adabna hiji2//mimitina 


\begin{abstract}
dina sahur/ /kadua dina leumpang//katiluna sok kaciri dina diuk/ /kaopat dina nangtungna/ /yén katingalina hiji2//.

Terjemahan bebas:

VII/06/192 //Ulama dan orang (jahat)/ /penakut dan berani/ durjana bobotoh ngadu/ /tua dan muda/ /perempuan dan lelaki/ /wataknya pasti terlihat//dalam dirinya sendiri//. VII/07/193 //Terlihat (dari) empat/ /bentuk (adab)/ /kesatu (saat) berbicara/ /kedua (saat) berjalan//ketiga (saat) duduk/ /keempat (saat) berdiri/ /akan terlihat satu-satu//.
\end{abstract}

Melalui cuplikan teks di atas dapat diketahui bahwa berperilaku di depan orang tidak ada perbedaan dalam memandang. Hal ini sama saja, yaitu setiap perilaku bisa dilakukan oleh siapa pun, tanpa pandang bulu. Dijelaskan bahwa setiap golongan, ulama atau maksiat, laki-laki atau wanita, penakut atau pemberani, semuanya dapat dilihat wataknya berdasar pada perilaku dalam dirinya sendiri saat berada di depan umum. Contohnya, jika manusia yang memiliki kedudukan yang tinggi, dan tidak ingin berdekatan dengan manusia yang lebih rendah, maka ia akan menjauh dari orang yang statusnya lebih rendah darinya. Hal itu dapat dilihat melalui pengamatan yang dilakukan terhadap lingkungan: mengamati orang lain dan membaca situasi.

Hal itu berbeda jika seorang yang memiliki ilmu luhur, akan bersedia duduk di mana pun, serta keluhuran ilmunya akan diketahui melalui pembicaraan dari mulutnya. Perilaku seperti itu yang lebih baik, bukan mengamati situasi dan memilah lingkungan, tetapi dapat masuk dan mempengaruhi melalui kecerdasan serta pengetahuan baiknya. Penjabaran ini menunjukkan bahwa perilaku yang memiliki ilmu akan berbeda jauh saat berada di depan umum.

Kemudian, jika manusia yang mengagungkan materi akan terlihat jika sedang berada dalam kerumunan. Setiap kalimat yang dibicarakan hanya berkaitan dengan banyaknya materi dan menyombongkan kepemilikan materi, selalu berkaitan dengan materi. Pembicaraan terhadap materi tidak akan pernah habis, serta cara menyombongkan materi tidak akan pernah berhenti. Maka, watak seperti ini harus dijauhi oeh setiap manusia, demi 
menjaga adab yang ada di depan umum. Hal seperti ini cukup sering terjadi di lingkungan sehari-hari.

Adab yang muncul di hadapan umum dapat menunjukkan watak seseorang, seperti yang sudah dijelaskan di bagian atas. Oleh karena itu, lebih baik menjadi seorang yang tanpa pandang bulu (memilih) saat di depan umum. Akan tetapi, melalui tanpa pandang bulu tersebut, dapat menonjolkan tingkat pengetahuan melalui pembicaraan yang bernilai. Jangan sampai seperti yang memiliki kedudukan dan tidak mau berada di tengah-tengah, serta yang memiliki harta yang selalu membicarakan materi dalam setiap kesempatan. Melihat manusia untuk menjalankan relasi horizontal, dapat dipandang menjadi pengetahuan dan penyadaran terhadap diri sendiri.

Watak manusia di depan umum dapat dilihat sepintas saat berbicara, duduk, berjalan, dan berdiri. Ketika berdiri akan terlihat bagaimana cara memandang dan mengamati setiap jengkal, kemudian saat melangkah akan terlihat ke mana yang dituju. Setelah itu, akan terlihat melalui duduk yang ada di sekitarnya, akan menunjukkan adab serta melalui pembicaraan yang ada setelah berkumpul dan duduk dengan golongan atau kelompoknya. Melalui pembicaraan tersebut, akan terlihat gambaran yang sudah dijabarkan yang merujuk pada: kedudukan, keilmuan, atau materi. Gerak-gerik manusia di depan umum dapat disaksikan dan menunjukkan wataknya yang erat dilakukan di hadapan umum.

Melalui penjabaran ini, muncul refleksi yang didapat dari pentingnya nilai adab dalam menjalin hubungan horizontal. Hal tersebut tidak dapat dipungkiri sebagai pengaruh kuat dan besar atas keterjalinan nilai sosial. Pengaruh yang besar atas refleksi nilai adab dapat dilihat dari perilaku yang tampak di lingkungan oleh setiap manusia. Dengan demikian, petuah dan peringatan sebagai nilai didaktis ini muncul dengan tujuan sebagai peringatan dan pengingat begitu besarnya pengaruh nilai adab atas hubungan horizontal yang terjalin.

Keterkaitan antara nilai adab yang terdapat dalam teks naskah $B A S$, tidak semerta-merta tanpa relevansi. Adanya nilai adab harus diperhatikan oleh manusia, akan berpengaruh terhadap hubungan dan relasi dalam menjalani hubungan horizontal. 
Oleh karena itu, untuk menjaga hubungan yang terjalin dan berkorelasi antaramanusia, setiap adab yang dilakukan dapat dijadikan refleksi diri sendiri di depan umum.

Nilai-nilai adab yang sudah dijelaskan di bagian atas tidak hanya sebatas nasihat. Semua yang sudah tertulis harus dijadikan pertimbangan dalam tingkah-laku. Hal tersebut harus diperhatikan lebih saksama, dengan mempertimbangkan keberadaan petuah sebagai pengetahuan dan batasan diri sendiri. Melalui pengejawantahan ini, sudah sepatutnya adab-adab baik diterapkan, sedangkan adab-adab buruk harus dijauhi. Melalui korelasai seperti ini, nasihat-nasihat yang sudah tersedia dapat memberikan pengaruh yang besar terhadap manusia dalam menjalani kehidupan sehari-hari.

Sebagai refleksi, adanya nilai kandungan di dalam naskah kuna merupakan hasil dari gejala sosial (lingkungan). Bentukbentuk peringatan yang terkemas di dalam nilai kandungan, secara eksplisit dan implisit dapat dijumpai. Selayaknya nilainilai yang tertulis dalam sebuah nasihat, sebagaian besar dapat ditemukan secara konkret bahwa bentuk-bentuk peringatan selalu disematkan dalam naskah kuna. Kekekalan sebuah teks dapat dipandang sebagai refleksi dan apikatif terhadap kehidupan.

Nasihat yang terdapat di dalam kandungan teks naskah yang begitu luhur, harus diperhatikan sebagai sebuah peringatan dan pengingat. Hal itu disinggung secara eksplisit dalam penyampaian berikut ini.

$\mathrm{VII} / 31 / 217$ //Jalma ngabantah papatah/ /anu bener éta jalma téh pasti/ /temahna manggih kaduhung//tangtu meunang doraka/.... XII/36/327 //Tangtu yén salamet diri/ /diréka ku kahadéyan/ /geuning mungguh pakarang gél /seukeutna sebab diasah//manusa ku piwulang/....

Terjemahan bebas:

VII/31/217 //Manusia yang membantah pepatah/ /selalu (merasa) benar//kelak akan menyesal/ /akan durhaka/.... XII/36/327 //Tentu diri akan selamat//dipenuhi dengan kebaikan//teguh dalam kebaikan//karena sering digunakan/ /manusia memahami pengajaran/.... 
Cuplikan di atas menunjukkan korelasi piwulang atau pepatah yang disampaikan melalui tulisan dalam naskah $B A S$. Korelasi seperti ini akan ditemui di setiap daerah di Nusantara yang sudah lebih dahulu mengenal adanya tradisi serta pemanfaatan tradisi tulis untuk menyimpan wasiat dan amanat kepada keturunan-kini. Oleh karena itu, pengungkapan setiap nilai adab di dalam teks, dapat memberikan pemahaman kepada masyarakat luas.

Sebuah refleksi di bagian akhir teks $B A S$, dapat dikatakan sebagai penutup yang menjadi amanat. Anjuran untuk berperilaku baik dan ketetapan hati sangat penting dilakukan. Sebagai gambaran, yang paling kecil dan berpengaruh berawal dari keyakinan dalam diri masing-masing. Berangkat dari hal tersebut, terbangunnya relasi hubungan horizontal semakin baik. Semua amanat penutup sebagai upaya menegaskan dapat dilihat melalui cuplikan teks berikut ini.

\begin{abstract}
$\mathrm{XIV/22/378} \mathrm{//Reujeung} \mathrm{deui} \mathrm{kudu} \mathrm{pada} \mathrm{éling//kapitutur}$ kolot//kudu pada bener haté genén/.... XIV/25/381//Ngan geus lumrah di jaman kiwari//anggepna sok béngkok//teu rumasa kudu(na) sing getén/ /di jero ati[na] sanajan éling/.... XIV/27/383 //Anu matak banget nya wawangsit/ /sing karep tatakon/....

Terjemahan bebas:

XIV/22/378 //Harus sadar (dipakai)/ /nasihat orangtua/ /harus memiliki keteguhan hati/.... XIV/25/381//Sekarang sering ditemui//sering melenceng/ /tidak merasa harus teguh/ /padahal di dalam hatinya ingat/... XIV/27/383 //Harus diingat (pesan)/ /untuk selalu teguh/....
\end{abstract}

Melalui cuplikan di atas, semakin menegaskan kompleksitas kandungan adab dalam teks naskah $B A S$. Pentingnya sebuah nasihat adab sebagai refleksi hubungan horizontal yang terjalin dalam kehidupan. Melalui penjabaran dan pemahaman ini, akan mengembalikan pandangan terhadap nilai-nilai yang sudah tertulis dan terekam dalam naskah kuna. Tidak hanya itu, sebagai refleksi dalam menjalani kehidupan sehari-hari, relevansi nilai yang terkandung sangat tepat untuk mengembalikan pemahaman terhadap sebuah nilai tradisi. 
Melimpahnya temuan penggunaan diksi yang menunjukkan penekanan, semakin menguatkan bahwa nilai yang terkandung begitu luhur. Relevansi keberadaan nilai serta hubungan horizontal yang terbangun akan semakin baik. Dampak seperti ini memberikan nilai lebih terhadap pandangan nilai kandungan naskah kuna, bukan hanya sekadar kekunoan yang muncul. Penekanan sebagai nasihat atas nilai yang terkandung memperlihatkan keluhuran warisan dalam bentuk naskah kuna. Pengejawantahan nilai kandungan harus dilakukan dengan tujuan untuk digali kembali, serta mengingatkan keberadaan warisan yang harus diteruskan dan tersampaikan dengan jelas.

Nilai kandungan dalam naskah $B A S$ patut mendapatkan perhatian lebih. Secara khusus, nilai adab yang sudah ada di setiap daerah di Nusantara akan merujuk pada kebaikan. Melalui salah satu hasil produk tradisi dan budaya di Tatar Sunda ini, tergambar sebuah konsep adab yang sudah tertulis dan dijadikan sebuah amanat yang harus tersampaikan. Pengungkapan juga harus dilakukan terhadap produk-produk tradisi dan budaya yang ada di daerah lain dengan tujuan untuk kembali membuka pemahaman masyarakat luas dalam memahami nilai-nilai yang terkandung.

Pengungkapan relevansi nilai kandungan membuka pengaruh positif dalam menghadapi gejala sosial yang sering terjadi. Semua perilaku yang ada, bukan sekadar reaksi atas aksi yang ada dari luar, tetapi terbangun dari hal yang kecil dan mendasar: diri sendiri. Pengungkapan nilai adab ini juga dapat menjadi refleksi terhadap diri sendiri dan lingkungan di sekitar. Semakin luas pengungkapan nilai kandungan, semakin berdampak dan memberikan pengaruh terhadap masyarakat luas. Hal inilah yang menjadi tujuan dari kajian yang berfokus pada pengungkapan nilai-nilai yang terdapat di dalam naskah kuna. Melalui kajian ini juga, bagian kecil dari budaya dan tradisi yang ada di Nusantara terungkap dan dapat disebarkan.

\section{SIMPULAN}

Nilai kandungan adab dalam naskah $B A S$ sangat dominan, secara umum dan khusus. Adab dalam ajaran Islam sangat relevan untuk menunjang hubungan antarmanusia, menjadi dasar 
atas nilai adab dalam kandungan teks $B A S$. Nilai adab yang terkandung meliputi; (1) watak tercela; (2) perilaku buruk; (3) adab di depan umum; (4) perilaku buruk di masyarakat; (5) watak buruk manusia; dan (6) cara memandak watak di depan umum. Upaya penyampaian nilai adab didorong atas kebutuhan zaman dan perilaku yang terjalin antarmanusia saat ini. Kajian ini membuktikan bahwa nilai-nilai kandungan dalam (teks) naskah kuna kekal, sebagai refleksi hubungan horizontal. Pengejawantahan nilai kandungan merupakan upaya pemahaman kepada masyarakat luas, "mengembalikan" warisan moyang yang tertulis dalam naskah kuna. Pengungkapan nilai-nilai dalam kandungan naskah kuna sangat diperlukan saat ini, sekaligus memberikan "kabar" dan "membuka" pemanfaatan kajian filologis yang paling dasar.

\section{DAFTAR PUSTAKA}

\section{Buku}

Brata, R. Satijadi. Rusiah Tembang Sunda. Djakarta: Balai Pustaka, 1952.

Danasasmita, Ma'mur. Wacana Bahasa Dan Sastra Sunda Lama. Bandung: STSI Press, 2001.

Darsa, Undang Ahmad. Kodikologi. Sumedang: FIB Unpad, 2016.

Kartono, Kartini. Pengantar Metodologi Research Sosial. Bandung: Alumni, 1983.

Mulyadi, Sri Wulan Rujiati. Kodikologi Melayu Di Indonesia. Jakarta: Fakultas Sastra, Universitas Indonesia, 1994.

Permadi, Tedi. Kodikologi Sebuah Pengantar Kajian Naskah. Bandung: FPBS UPI, 2011.

Zuriyah, Nurul. Pendidikan Moral Dan Budi Pekerti Dalam Perspektif Perubahan. Jakarta: Bumi Aksara, 2007.

\section{Artikel}

Arps, Bernard. "Kepekaan Filologis Untuk Pengkajian Budaya." Manuskripta 10, no. 2 (2020): 177-191. 
Ekowati, Venny Indria, Sri Hertanti Wulan, Aran Handoko, and Nur Hanifah Insani. "Ajaran Budi Pekerti Dalam Iluminasi Naskah Babad Kartasura-Sukawati." Manuskripta 8, no. 1 (2018): 12957.

Fathurahman, Oman. "Karakteristik Naskah Islam Indonesia: Contoh Dari Zawiyah Tanoh Abee, Aceh Besar," Manuskripta 1, no. 1 (2011): 123-145.

Kamidjan, Kamidjan. "Naskah Serat Wulang Sunu Sebuah Sastra Didaktis: Kajian Filologi." Jurnal Pena Indonesia 1, no. 2 (2015): 216-239.

Mumfangati, Titi. "Kajian Nilai Budaya Dalam Serat Wulang Pandhita Tekawardi," Patrawidya 18, no. 2 (2017): 203-219.

Rohman, Syaiful, and Dewaki Kramadibrata. "Piwulang Dalam Serat Darmasaloka." Jumantara: Jurnal Manuskrip Nusantara 9, no. 2 (2018): 223-238.

Siswayanti, Novita. "Javanese Ethical Values in Tafsir Al-Huda." Analisa Journal of Social Science and Religion 20, no. 2 (2013): 207-220.

Wangsa, Bremara Sekar, Edy Tri Sulistyo, and Suyanto Suyanto. "Makna Budi Pekerti Remaja Pada Serat Wulangreh Karya Pakubuwono IV: Pupuh Macapat Durma." Mudra Jurnal Seni Budaya 34, no. 3 (2019): 325-329.

Wardhana, Christiana Dwi. "Ajaran Catur Budi Dalam Serat Sasanasunu Karya Kyai Yasadipura II.” Jumantara: Jurnal Manuskrip Nusantara 5, no. 1 (2014): 150-159.

_. "Ajaran Nistha-Madya-Utama Dalam Beberapa Teks Jawa." Jumantara: Jurnal Manuskrip Nusantara 1, no. 2 (2019): 1-10. 


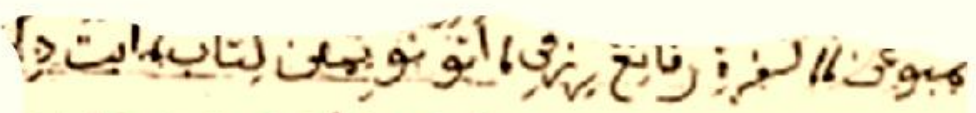

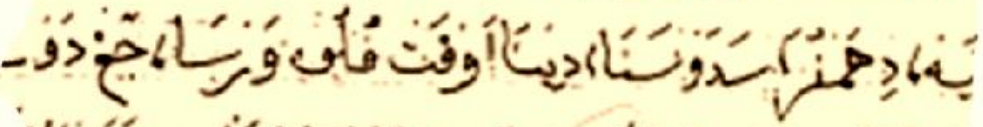

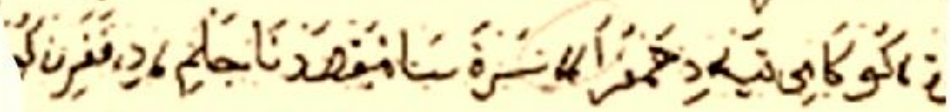

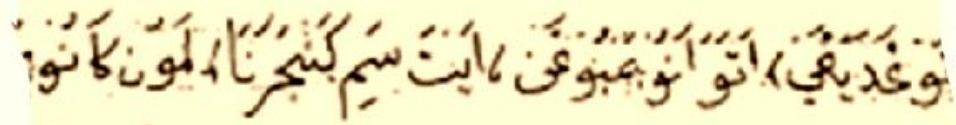

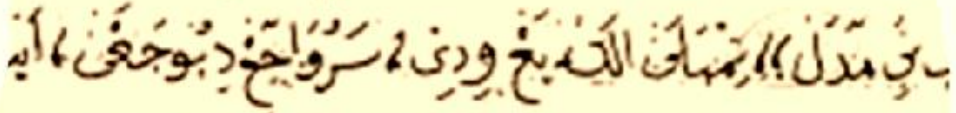

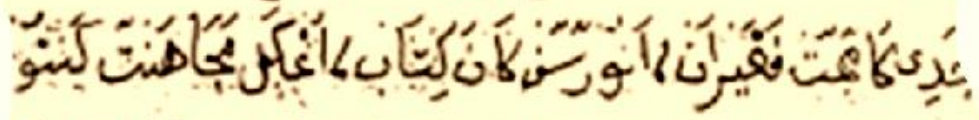

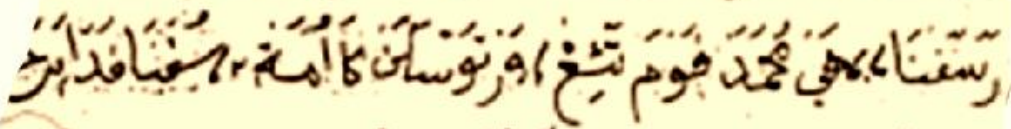

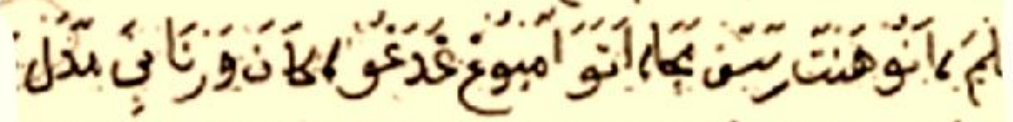

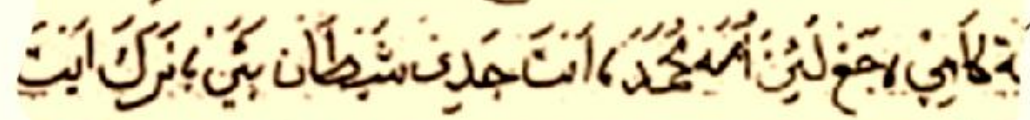

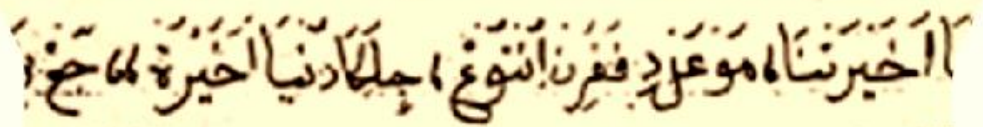

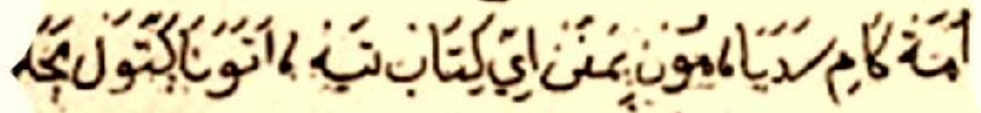

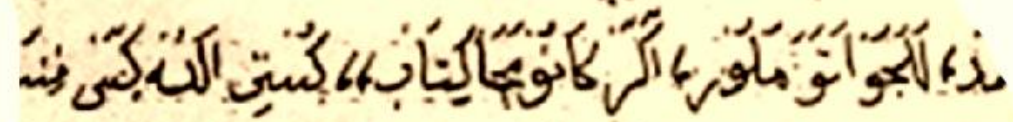

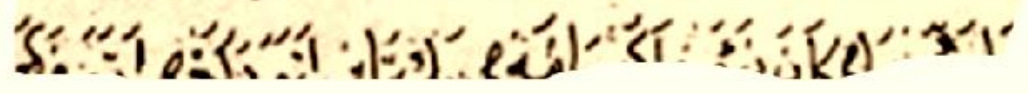

